\title{
WTO ADJUDICATION@ me.too: Are Global Public Goods like the World Trade Organization Owned by Governments or by Peoples and Citizens?*
}

\section{Ernst-Ulrich Petersmann ${ }^{* *}$}

As the most frequent and most successful user of the dispute settlement system of the WTO, the US has welcomed judicial clarifications by WTO dispute settlement bodies whenever they confirmed legal claims of the US. Yet, the Trump administration increasingly rejects judicial findings against the US trade restrictions as violating the WTO prohibitions of "add(ing) to or diminish(ing) the rights and obligations provided in the covered agreements." This contribution criticizes the illegal US 'blocking' of the WTO Appellate Body and the underlying, hegemonic nationalism and protectionist interest group politics. It suggests that reasonable and responsible citizens benefitting from the WTO trading, legal and dispute settlement systems must resist illegal power politics, for instance, by supporting a WTO Adjudication@me.too "enlightenment campaign" pressuring democratic institutions and governments to protect rule of law and judicial remedies in international trade as prescribed by parliaments when they approved the WTO Agreement.

* This paper is an expanded and updated version of the author's Guest Post: WTO ADJUDICATION@me.too: Hidden in plain sight, published at International Trade Law and Policy Blog, available at https://ielp.worldtradelaw. net/2020/03/guest-post-wto-adjudicationmetoo-hidden-in-plain-sight.html. All websites cited in this article were last visited on May 1,2020.

** Emeritus Professor of International and European Law at the European University Institute, Florence (Italy); Former legal advisor in the German Ministry of Economic Affairs, GATT and WTO; and former secretary, member or chairman of GATT and WTO dispute settlement panels. The author was secretary of the Uruguay Round Negotiating Group 13 that elaborated the WTO Dispute Settlement Understanding. Dr. iur. (Heidelberg). The author may be contacted at: Ulrich. petersmann@eui.eu / Address: European University Institute, Via Bolognese 156-50139 Firenze, Italy. 


\author{
Keywords \\ WTO, Appellate Body, Constitutionalism, Human Rights, Judicial Remedies, \\ Public Goods, Public Reason.
}

\title{
I. From Apology to Utopia? Need for "Critical Legal Positivism"
}

Public international law historically evolved as a power-oriented legal system regulating rights and duties of governments and states. Yet, since the American and French democratic revolutions during the 18th century, the recognition of 'inalienable' human rights laid down in the US Declaration of Independence (1776) and the French Declaration of the Rights of Man and the Citizen (1779) provoked progressive challenges of state-centered conceptions of "international law among sovereign states." Slaves, religious minorities, women, workers and other suppressed citizens increasingly invoked the declared human rights and revolutionary practices in France and the US. Following World War I, workers and trade unions pressured their governments to establish the "Constitution of the International Labor Organization" ("ILO") - as Part XIII of the Peace Treaty of Versailles (1919) - proclaiming in its Preamble, inter alia:

\begin{abstract}
Whereas universal and lasting peace can be established only if it is based upon social justice; and whereas conditions of labor exist involving such injustice, hardship and privation to large numbers of people as to produce unrest so great that the peace and harmony of the world are imperiled'.....; whereas also the failure of any nation to adopt humane conditions of labor is an obstacle in the way of other nations which desire to improve the conditions in their own countries; the High Contracting Parties, moved by sentiments of justice and humanity as well as by the desire to secure the permanent peace of the world, and with a view to attaining the objectives set forth in this Preamble, agree to the following Constitution of the International Labor Organization.
\end{abstract}

It was only in response to World War II that, in the 1944 ILO Declaration Concerning the Aims and Purposes of the ILO, member states could agree on a list of "fundamental principles" (like "labor is not a commodity"; "freedom of expression and of association are essential to sustained progress"), human and labor rights (like the "right to collective bargaining") and state obligations (e.g. to promote "full employment and the raising of standards of living," "extension of social security measures to provide 
a basic income to all in need of such protection and comprehensive medical care," "adequate protection of the life and health of workers in all occupations," "provision of child welfare and maternity protection").

The UN Charter and the 1948 Universal Declaration of Human Rights responded to the tragedies of war and holocaust by basing the UN Charter not only on "sovereign equality of states," but also on "recognition of the inherent dignity and of the equal and inalienable rights of all members of the human family (as) the foundation of freedom, justice and peace in the world." "They recognized that "human rights should be protected by the rule of law,", and included, inter alia, everyone's "right to take part in the government of his country, directly or through freely chosen representatives."4 The universal recognition of civil, political, economic, social and cultural human rights in dozens of the UN and regional human rights conventions, the recognition of the 'inalienable' and 'indivisible' character of these human rights, and their incorporation into national Constitutions adopted by most of the 193 UN member states entailed a "paradigm change" transforming the "international law among sovereign states" into an "international law of states, peoples and citizens" with inalienable human and democratic rights (e.g. to popular self-determination). The legal empowerment of peoples and citizens not only induced "struggles for justice" like decolonization. It also progressively transformed the state-centered "international law of coexistence" into a citizen-oriented "international law of cooperation" for collective protection of public goods (PGs) based on human and constitutional rights of citizens (notably in European human rights and economic integration law) recognizing that "all human beings are born free and equal in dignity and rights," "endowed with reason and conscience and should act towards one another in a spirit of brotherhood." "The universal recognition of 'inalienable' and 'indivisible' human rights also reflects recognition of the sociological fact that civil, political, economic, social, cultural, moral and legal orders are interdependent and dynamically interact.

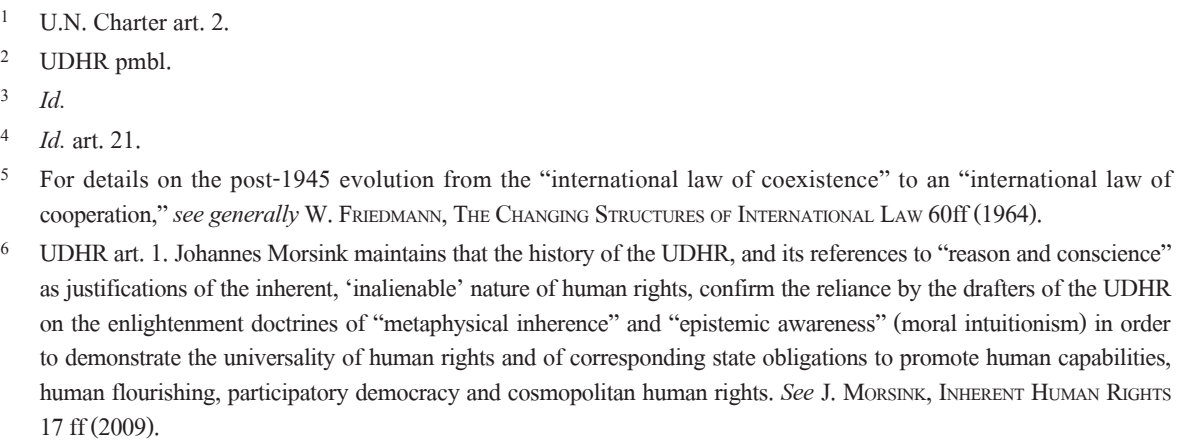
as justifications of the inherent, 'inalienable' nature of human rights, confirm the reliance by the drafters of the UDHR on the enlightenment doctrines of "metaphysical inherence" and "epistemic awareness" (moral intuitionism) in order to demonstrate the universality of human rights and of corresponding state obligations to promote human capabilities, human flourishing, participatory democracy and cosmopolitan human rights. See J. MorsinK, InHERENT Human Rights $17 \mathrm{ff}(2009)$. 
Social peace depends not only on recognition and overall coherence of these complex interdependencies, as promoted by the incorporation of constitutional safeguards of human rights, rule-of-law, democracy principles and judicial remedies into national and international legal systems. In a globalizing world, the progressive realization of "world order treaties" (like the UN Charter, human rights, WTO and environmental agreements) also depends on empowering citizens, their democratic institutions and courts of justice to limit intergovernmental power politics, as illustrated by the jurisprudence of regional human rights courts, regional economic integration courts, or investor-state arbitration protecting individual rights against abuses of power. As all international treaties use indeterminate legal terms, they are confronted with the problem that judicial clarifications of rules aimed at protecting public goods (like rule of law) risk being rejected by apologetic claims that governments did not consent to specific rule-clarifications interpreting treaty texts in their context with due regard to general treaty principles and treaty objectives. Inducing "rational egoists" to limit their often 'destructive,' apologetic abuses of freedoms and "sovereign equality" of states by "constructive protection of PGs" depends on "institutionalizing public reason" through progressive transformation of agreed "principles of justice" into implementing legislation, administration and judicial protection of equal rights of citizens and their states.

My textbook, InTERnational ECONOMic LAW In THE 21st Century emphasizes the need for "critical legal positivism," for instance, in view of the fact that "inalienable human rights" and other "principles of justice" have become incorporated into positive legal systems (e.g. as parts of international treaty law, general international law and the applicable law of national and international "courts of justice"). ${ }^{7}$ The surface level of the "law in the books," the underlying legal practices and cultures (e.g. power-oriented "member-driven governance" in GATT and WTO), and the deep structures of legal systems (like 'inalienable' human and democratic rights of citizens recognized by the WTO member states) constantly interact in complex ways, for instance when-since the 1960s-the "embedded liberalism" underlying the GATT was successfully adjusted to decolonization leading to GATT membership of ever more independent, less-developed countries ("LDCs") and their increasing claims to limit the power-oriented traditions of international economic law by better protection of LDCs and their citizens. The more globalization transforms national into transnational PGs which no state can unilaterally protect without international law and institutionalized international cooperation (e.g. to limit global health pandemics

7 See generally E.-U. Petersmann, International Economic Law in the 21st Century. Constitutional Pluralism and Multilevel Governance of Interdependent Public Goods 1ff (2012). 
and climate change), the more it becomes necessary to extend the safeguards of democratic constitutionalism. For example, abuses of national governance powers must be further restrained also in multilevel governance of transnational PGs-like human rights, the global division of labour protected by the law of the 1944 Bretton Woods institutions and the WTO, or protection gainst global health pandemics through cooperation in the World Health Organization ("WHO") - so as to limit collective action problems, for instance, by promoting "club goods," limiting abuses of executive powers (like President Trump's imposition of discriminatory import tariffs up to USD 350 billion violating the WTO law), and protecting rule of law and social justice in international economic, health and environmental cooperation. How should citizens, their democratic institutions and the WTO governments respond to the recent US attacks on the WTO legal and dispute settlement system and to the illegal 'blocking' by the US of the filling of the WTO Appellate Body ("AB") vacancies, ushering in the incapacity of the $A B$ - since December 10, 2019-to accept new appeals? Can the utopia of the UN and the WTO "sustainable development goals" be realized if governments, their peoples and citizens fail to protect impartial third-party adjudication of disputes "providing security and predictability to the multilateral trading system," as prescribed in Article 3.2 of the WTO Dispute Settlement Understanding ("DSU") as a legal restraint on illegal power politics?

\section{Struggles for Justice and Judicial Remedies in National and International Law}

Humanity knows from Greek mythology and from the Bible that third-party adjudication emerged and developed in response to never-ending human tragedies (like the pursuit of Orest by the goddesses of revenge punishing Orest's murder of his mother, because she had killed his father Agamemnon who had sacrificed their daughter Iphigenia on his way to lead the Greek battle against Troye). Since the trial of Orest in Athena's Aeropag, the trial of Socrates in the ancient constitutional democracy of Athens, or the trial of Jesus under the Roman rulers Herodes and

8 On the economic distinction between private goods, non-excludable and non-exhaustible "pure PGs," non-exaustible "impure PGs," and non-excludable "common pool resources," their respective "collective action problems," and the legal strategies for limiting market failures, governance failures and "constitutional failures" (like formation of 'clubs' limiting free-riding among WTO members and among citizens), see generally E.-U. Petersmann, Multilevel Constitutionalism for Multilevel Governance of Public Goods. Methodology Problems in International Law (2017). 
Pilatus, humanity has learned that tribunals-even in constitutional republics since ancient Rome-need to be constrained by principles of justice and due process of law. Since World War II, human rights to judicial remedies ("access to justice") have become recognized in ever more national Constitutions, human rights treaties and economic law treaties. ${ }^{9}$

Like the Permanent Court of International Justice was created in response to World War I, so were the International Court of Justice, the European Court of Human Rights, many national Constitutional Courts (e.g. in Germany) and European Courts responses to the tragedies of World War II. Human tragedies continue, and so do the human responses of establishing new national and international courts, like national criminal courts and the International Criminal Court in response to crimes against humanity, or the WTO AB in response to the previous failures of the GATT dispute settlement system. Nationalist rulers - also in many democracies, including in European Union countries like Poland-challenge national and international courts, especially if judges (including WTO judges)-or the US Congress - dare holding rulers accountable. The US trade wars against China and US threats of trade sanctions against other WTO members ignore the WTO rules and dispute settlement procedures, just as China's military expansion in the South China Sea ignores the arbitral award rendered under the UN Law of the Sea Convention, and Russia ignores the arbitral award rendered by the Permanent Court of Arbitration in Russia's investment dispute with the expropriated shareholders of the former Yukos oil company. ${ }^{10}$ How should citizens and their democratic institutions respond to the illegal de facto destruction of the WTO's AB and to intergovernmental power politics (like the US blocking of the $\mathrm{AB}$ ) disregarding the will of parliaments when they approved the WTO Agreement and, in many countries, incorporated it into their domestic legal systems?

According to Article 17.2 of the DSU, vacancies of the seven AB members "shall be filled as they arise." Since the end of the terms of two AB members on December 10,2019 , there is only one single AB member left, making the appeals function of the WTO dysfunctional. ${ }^{11}$ The unprecedented and unconvincing attacks against the WTO $\mathrm{AB}$ in the 2020 USTR Report $^{12}$ and in the speech by the former WTO AB member Tom

9 The Access of Individuals to International Justice (M. Kamto \& Y.Tyagi eds., 2019).

10 Yukos Universal Ltd v. Russia, PCA Case Repository. Case No AA 227 (Perm. Ct. Arb. July 18, 2014), available at https://www.italaw.com/sites/default/files/case-documents/italaw3279.pdf.

11 At least three AB members are needed as a 'quorum' for forming an AB Divison considering an appeal of a panel report. See DSU art. 17(1).

12 USTR, Report on the Appellate Body of the WTO, Washington (Feb. 11, 2020), available at https://ustr.gov/about-us/ policy-offices/press-office/press-releases/2020/february/ustr-issues-report-wto-appellate-body. 
Graham on March 5, 2020, ${ }^{13}$ the UK's rejection of any control by the European Court of Justice over the future EU-UK Partnership Agreement, the limitation of investment adjudication in the USMCA Free Trade Agreement, and the reactions of some NorthAmerican legal commentators (like "the Appellate Body is gone-Let it rest") are reminders of the often ambivalent role of lawyers and of advocates of neo-liberalism in humanity's struggles for constraining political by judicial powers. Court houses in all 164 WTO members are decorated by statues symbolizing justice by blind-folded women holding a scale and a sword. The two statues representing Justice and Peace, which flank the main entrance to the WTO's headquarter at Lake Geneva, recall what WTO publications, the International Chamber of Commerce and also many American lawyers emphasize long since: rules-based multilateral trading systems play a crucial role in promoting peace. In his book on Supreme InJUSTICE: SLAVERY in the NATION's Highest COurt, American history professor P. Finkelman recalls how the "slavery jurisprudence" of the three most important, pre-civil war US Supreme Court justices (Marshall, Taney and Story) contributed to the US civil war responding to a systemic hostility in US law to human rights and social justice. ${ }^{14}$ American law professor R.H.Fallon, in his book on LAW AND Legitimacy in the Supreme Court, ${ }^{15}$ concurs with other US constitutional lawyers that the politicization of the US Supreme Court judges and judgments calls into question the legitimacy and reputation of the Court. Recent critics of the US Supreme Court, like A. Cohen's book, SuPREME INEQUALITY: The Supreme Court's Fifty-Year Battle for a More Unjust America (2019), point to social injustices, which the Court's jurisprudence continues to cause by often protecting powerful rather than vulnerable interests. ${ }^{16}$ Is the WTO AB crisis just another illustration of this politicization of independent, impartial third-party adjudication by the American interest group politics?

\section{Neo-liberalism vs Ordo-liberalism: Beware the 2020 USTR Report on the WTO Appellate Body}

In his recent book on GLOBAlists: The END of EMPIRE AND the BirTh OF NeOLIBERAlism

13 Text published in: International Economic Law and Policy Blog (Mar. 9, 2020), available at https://ielp.worldtradelaw. net/2020/03/tom-graham-on-the-appellate-body.html.

14 P. Finkelman, Supreme Injustice: Slavery in the Nation’s Highest Court 76ff (2018).

15 R. Fallon, Law and Legitimacy in the Supreme Court $155 \mathrm{ff}$ (2018).

16 A. Cohen, Supreme Inequality: The Supreme Court's Fifty-Year Battle for a More Unjust America 309ff (2019). 
(2018), history Professor Q. Slobodian describes the WTO as "the paradigmatic product of Geneva School neoliberalism," and the "creation of the WTO (as) a crowning victory of the neoliberal project of finding an extra-economic enforcer for the world economy in the twentieth century."17 Yet, like many other Anglo-Saxon commentators on neo-liberalism, Slobodian overlooks the categorical differences between Anglo-Saxon neo-liberalism and European ordo-liberalism. American neo-liberalism and Chicago School economists prioritize liberalization of market access barriers, deregulation, privatization and financialization of markets in order to empower utilitarian market actors (homo economicus) to pursue their self-interests and enhance the self-regulating forces of market competition as spontaneous information, coordination and sanctioning mechanisms. ${ }^{18}$ The German, European and Virginia Schools of ordo-liberalism perceive markets as legal constructs (rather than as gifts of nature), which cannot maximize general consumer welfare without legal limitations of market failures, governance failures and "constitutional failures."19 The GATT/WTO jurisprudence (e.g. on interpreting GATT/WTO rules as protecting non-discriminatory conditions of competition) emphasized the systemic, ordoliberal functions of states and of the GATT/WTO legal and dispute settlement systems as 'guardians' of non-discriminatory conditions of competition. The USTR Report on the AB of February 2020 perceives the WTO law as an instrument of US power politics and disregards ordo-liberal "constitutional economics" justifying the multilateral WTO legal and dispute settlement systems. ${ }^{20}$

The legal justifications by the Trump administration of their illegal 'blocking' of the WTO AB nominations insist on the US interpretations of the WTO rules and the US criticism of $A B$ findings without any evidence that legal interpretations by the $A B$ violated the customary rules of treaty interpretation or the (quasi)judicial $\mathrm{AB}$ mandate for impartial, independent and prompt third-party adjudication through quasiautomatic adoption of the WTO panel and AB reports by the Dispute Settlement Body ("DSB”). The 2020 USTR Report-notwithstanding its valid criticism of some WTO rules and dispute settlement practices (e.g. that the AB no longer consults with the parties when deciding to disregard the Article 17.5 deadline, the AB definition of "public body" in Article 1 of the WTO Subsidy Agreement)-suffers from legal biases

17 Q. Slobodian, Globalists: The End of Empire and the Birth of Neoliberalism 23-5 (2018).

18 For a detailed comparison of Anglo-Saxon neo-liberalism and European ordo-liberalism, see E.-U. Petersmann, Economic Disintegration? Political, Economic and Legal Drivers and the Need for 'Greening Embedded Liberalism, 22 J. INT'L ECON. L. (forthcoming 2020).

19 For detailed analyses, see Petersmann id. (n. 18).

20 USTR Report, supra note 12. 
and incorrect claims such as:

- US denial of (quasi)judicial functions of WTO third-party adjudication, even though numerous WTO publications and WTO dispute settlement reports over more than 20 years acknowledged the (quasi)judicial mandates of WTO dispute settlement bodies (i.e. WTO panels, the AB and the quasi-automatic adoption of their reports by the DSB);

- US disregard for judicial AB arguments in the performance of the DSU's mandate "to clarify the existing provisions of those agreements in accordance with customary rules of interpretation of public international law" (Article 3 DSU), for instance whenever the $\mathrm{AB}$ found compliance with the time limit of 90 days (Article 17.5 DSU) - which was imposed by US negotiators in 1993 notwithstanding the widespread criticism that no other court seems to be limited by such an unreasonably short time limit-impossible to reconcile with the other $\mathrm{AB}$ tasks (e.g. due to illegal US blocking of the filling of $\mathrm{AB}$ vacancies);

- contradictory USTR claims that AB legal findings against the US violated the DSU prohibition to "add or diminish the rights and obligations in the covered agreements" (Article 3.2 DSU) - even if the AB had justified these legal findings on the basis of the customary rules of treaty interpretation and its (quasi)judicial mandate -, notwithstanding the USTR's regular support of AB reports accepting "creative WTO interpretations" advocated by the USTR as a legal complainant;

- US description of US "zeroing practices" as a "common-sense method of calculating the extent of dumping" 21 even if their biases had been consistently condemned by the AB and DSB as violations of the WTO obligations of "fair price comparisons" (which are hardly mentioned in the USTR report);

- one-sided focus on WTO texts as interpreted by US negotiators without regard to the customary law and DSU requirements to clarify the meaning of the often indeterminate WTO provisions with due regard also to WTO legal texts revealing the "context, object and purpose" of WTO provisions and the explicitly recognized "systemic character" of what the WTO Agreement calls "this multilateral trading system" (Preamble) and its "dispute settlement system" (Article 3 DSU);

- denigration of $\mathrm{AB}$ members as "three unelected and unaccountable persons" 22 whose "overreaching violates the basic principles of the United States Government" (USTR Report, Introduction), notwithstanding the election of $\mathrm{AB}$ members through consensus decisions of 164 DSB member governments (including the US), their (quasi)judicial mandate, and the approval of WTO agreements (including the DSU) by the US government and US Congress;

- insulting claims that the AB Secretariat has weakened the WTO dispute 
settlement system by not respecting WTO rights and obligations. ${ }^{23}$

The USTR Report acknowledges that its purpose "is not to propose solutions." "24 The USTR Report repeats what the US ambassador has stated in DSB meetings since 2017: "WTO Members must come to terms with the failings of the Appellate Body set forth in this Report if we are to achieve lasting and effective reform of the WTO dispute settlement system. ${ }^{25}$ Yet, nothing suggests that - if WTO members should accept the false US claims of the AB's "persistent overreaching [...] contrary to the Appellate Body's limited mandate," and "the Appellate Body's failure to follow the agreed rules" - the US would be willing to comply with its DSU obligation of filling $A B$ vacancies "as they arise" 26 and return to the WTO third party adjudication, appellate review and customary rules of treaty interpretation (including "judicial interpretations" in the "prompt settlement of WTO disputes) as prescribed in the DSU. Past WTO members' 'appeasement' of false USTR claims (e.g. in Ambassador Walker's informal mediation proposal for overcoming the WTO dispute settlement crises) never changed the USTR's refusal to return to the WTO third party adjudication as prescribed in the DSU.

The "Economic and Trade Agreement" signed by China and the US on January 15, 2020 provides for discriminatory Chinese commitments to buy the US products, discriminatory US import tariffs and trade restrictions (e.g. targeting Chinese technology companies) without third-party adjudication. This bilateral "opt-out" - by the two largest trading nations - from their WTO legal and dispute settlement obligations seems to be the policy option preferred by those USTR officials who pursue additional "bilateral US trade deals"; they now publicly reflect also on the US withdrawal from the WTO Agreement on Government Procurement, and on 'unbinding' US tariff and market access commitments, in order to better use power asymmetries in rebalancing bilateral US trade deficits through bilateral reciprocity negotiations, as advocated by Trump's trade policy advisor P. Navarro. ${ }^{27}$ The US-China trade deal provides for dispute settlement through unilateral USTR determinations;

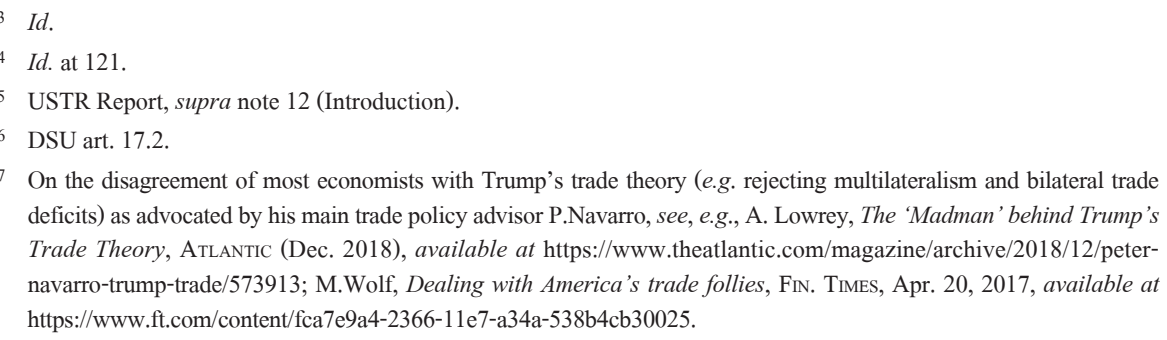
deficits) as advocated by his main trade policy advisor P.Navarro, see, e.g., A. Lowrey, The 'Madman' behind Trump's Trade Theory, AtLANTic (Dec. 2018), available at https://www.theatlantic.com/magazine/archive/2018/12/peternavarro-trump-trade/573913; M.Wolf, Dealing with America's trade follies, Fin. Times, Apr. 20, 2017, available at https://www.ft.com/content/fca7e9a4-2366-11e7-a34a-538b4cb30025. 
this unilateralism illustrates the hegemonic trade mercantilism, which USTR Lighthizer would like to impose on the rest of the world. In fact, the Trump administration already disregards the WTO rules (e.g. GATT Articles I, II and III) and dispute settlement procedures whenever it suits American political interests and the US interest group politics.

Hence, the WTO members willing to defend the multilateral WTO legal and dispute settlement system should beware of hegemonic US power politics undermining the WTO law and denying global PGs like multilateral trade and environmental protection systems. The response to the USTR demand of 'why' the WTO dispute settlement crises have emerged seems obvious. As the WTO members have failed to adequately control the WTO jurisprudence (e.g. through a DSB "legal committee" preparing majoritarian, "authoritative interpretations" of WTO rules in response to controversial AB interpretations of WTO rules), the Trump administration prioritizes mercantilist power politics rejecting multilateral legal and judicial restraints on its "asymmetric deal-making." The response to the question of 'how' to reform the WTO dispute settlement system must be to defend, and reform the rules-based, multilateral trading system, while continuing pragmatic use of Article 25 of DSU (appellate arbitration) as a temporary substitute for circumventing the illegal US blocking of the WTO AB system. Appeasement of the US destruction of the WTO legal and dispute settlement systems has systemic repercussions far beyond the WTO. Without a multilateral WTO dispute settlement system, not only the UN's goals for sustainable development, climate change mitigation and future WTO negotiations, but also the US' efforts at inducing market-oriented reforms in China's totalitarian state-capitalism are unlikely to succeed. Authoritarian strongmen may benefit from intergovernmental power politics and neo-liberal interest group politics. Yet, citizens all over the world will suffer from neglect of the ordo-liberal task of limiting governance failures and "constitutional failures" in multilateral governance of transnational PGs.

\section{Contradictions between Tom Graham's "2013 Speech" as an AB Member and his "2020 Speech" as a Washington Trade Remedy Lawyer}

Tom Graham is one of Washington's best-known trade remedy lawyers and served on the AB from 2011 until December 10, 2019. On February 6, 2013, he gave a public speech on "It Sure Looks Different From the Inside: Deciding International Disputes 
at the WTO" at Hofstra University Law School in the US, ${ }^{28}$ in which he emphasized, inter alia:

- AB members, "although they don't call us that, are in effect judges, on what is in effect the highest appeals court for the rules of global trade," "applying a legal craft"; "it is as craftsmen-not statesmen-that we work together to get it right"; "we are the final arbiters of what the rules of international trade mean";

- the AB staff "serves the Appellate Body as a whole-that is, Members don't have their own law clerks - which contributes to the sense of group commitment and collegiality, that is part of our tradition"; "the sense of responsibility and dedication to the institution of my fellow Members have been enormously impressive, as has been the extraordinary ability and dedication of our truly great multinational staff";

- "No decision of the Appellate Body has ever been overturned by the WTO Dispute Settlement Body-the committee of the whole WTO membership that oversees us"; "losing governments have complied with all but a very small handful of our decisions in 110 cases over the past 18-year history of the Appellate Body. In terms of the percentage of disputes resolved successfully, and the record of compliance, this is perhaps the most successful international dispute settlement system in the history of the world,"

- "As a practical matter, we have the final word not only in deciding cases but also in creating a body of jurisprudence for this global trade institution that is still new in the sense of the usual timeframe for creating international law."

In his speech on "The Rise (and Demise?) of the WTO Appellate Body" on March 5, 2020, back in Washington after the end of his term as an AB member, Graham contradicted his legal findings in his 2013 speech, ${ }^{29}$ for instance, by:

- criticizing "an orthodoxy of viewpoint about the role of the Appellate Body as a self-anointed international court, with much broader authority to overreach the rules and create judge-made law than I thought was permitted by the WTO agreements, or intended by the negotiators who created them"; as a result, "the Appellate Body acting like a court ... was not accountable to anyone"; "the negotiating history strongly indicates that (the $A B$ ) was intended not as an international court, but as a check on occasional egregious mistakes by panels";

28 T. Graham, It Sure Looks Different from the Inside: Deciding International Disputes at the WTO, Philip J. Shapiro Endowed International Visiting Scholar Lecture, June 2, 2013, available at https://pdfs.semanticscholar.org/f76f/88930 3add145bdcaad7d7aa4dc13bc45f5a3.pdf.

29 Henry Gao, It Sure Looks Different from the Inside, and Now the Outside Too (or 'Graham on Graham'), International Economic Law and Policy Blog (Mar. 11, 2020), available at https://ielp.worldtradelaw.net/2020/03/it-sure-looksdifferent-from-the-inside-and-now-the-outside-too-or-graham-on-graham.html. For the text of Graham's 2020 speech, see supra note 13. 
- proposing to " $(\mathrm{p})$ rohibit anyone other than the team-deciders, and staff working directly on a case-from discussing the case" ("no private lobbying of individual deciders by staff leadership not part of the team on the case');

- Belief in a single, correct interpretation, and seeking it through expanded analyses, encouraged gap filling and overreach. It made the Appellate Body strain to look for that "one correct" interpretation instead of asking whether the panel made a serious error, whether the challenged measure was prohibited by the rules as written';

- stretching "the words of agreed text, and to stretch decisions beyond merely resolving a particular dispute so as to create a body of jurisprudence, or to head off future disputes, (was) beyond the Appellate Body's mandate'; an undue adherence to precedent ... bake in mistakes."

According to Graham, his criticism of 2020 reflects his seven years of practical experiences as an AB member. He said: "increasingly as I saw things from the inside, I mostly agreed with what has been [...] the overall view of the United States as to the Appellate Body's proper role as negotiated by governments and written into the WTO Dispute Settlement Understanding. And I mostly agreed with the US critique of the Appellate Body's departure from that proper role." 30 Yet, neither the USTR's denial of (quasi)judicial WTO dispute settlement functions nor the USTR's claims of the $\mathrm{AB}$ exceeding its powers by violating the DSU prohibitions of "add(ing) to or diminish(ing) the rights and obligations provided in the covered agreements" (Articles 3.2 and 19.2 of DSU) are convincing:

- Even though "hidden in plain sight," WTO law prescribes impartial, independent and compulsory third-party adjudication of WTO disputes. Notwithstanding the deliberate avoidance, at the insistence of USTR negotiators in 1993, of references to 'judges', 'courts' and 'adjudication' in the DSU treaty provisions, the (quasi) judicial dispute settlement mandate is emphasized in the DSU (again, "hidden in plain sight"), in WTO working procedures for WTO panelists, AB members and arbitrators, in numerous WTO dispute settlement reports, annual AB reports, official WTO publications, hundreds of books and thousands of articles published by WTO lawyers over the past 25 years. For years, even the official "WTO badge" given to AB members by the WTO Secretariat used the title 'judge' (until this administrative practice was terminated by a WTO Deputy DirectorGeneral from the USA).

- All practicing WTO adjudicators (panelists, AB members, arbitrators) and WTO litigators representing WTO member governments (except some USTR lawyers and their trade remedy clientele) have consistently acknowledged the (quasi) 
judicial duties for independent, impartial, "prompt settlement" of WTO disputes through, inter alia, clarifications of "the existing provisions of those agreements in accordance with customary rules of interpretation of public international law" (Article 3 DSU). In his 2013 speech, Graham convincingly described these tasks of $\mathrm{AB}$ members as "judges applying a legal craft - not statesmen." ${ }^{, 31}$ As all $\mathrm{AB}$ reports have been (quasi)automatically adopted by 'negative consensus' decisions of the DSB, their legal interpretations and clarifications of WTO rights and obligations-including interpretation as: (1) a "process of cognition" (e.g. of the common intentions of the law-maker as declared in the legal texts, whose words may have different meanings); (2) an "act of volition" and choice by the interpreter constrained by the customary rules of treaty interpretation, and (3) as an "authoritative rendering of the meaning of the applicable rules of law" for the settlement of the specific dispute ${ }^{32}$-have been exclusively determined by the $A B$, even if the legally binding nature of the dispute settlement rulings derived from the adoption of panel and AB reports by the DSB.

- According to the AB's long-standing jurisprudence, the WTO legal interpretations clarifying WTO provisions in conformity with the customary rules of treaty interpretation-as prescribed in Article 3 DSU-cannot simultaneously violate the DSU prohibitions (inserted into the draft DSU in 1993 at the request of US negotiators) of "add(ing) to or diminish(ing) the rights and obligations provided in the covered agreements" (Articles 3.2 and 19.2 DSU). ${ }^{33}$ Having served myself as secretary to the Uruguay Round Negotiating Group 13 that elaborated the DSU, I recall that this same legal reservation was expressed during the drafting of Articles 3 and 19 DSU when these DSU provisions were inserted into the draft text upon the insistence of the USTR even though-as pointed out by other negotiators-no similar provisions exist in the founding texts for other international court and dispute settlement bodies.

Graham's justification, as a trade remedy lawyer back in Washington, of his support for the lack of respect for the $\mathrm{AB}$ by the Trump administration ${ }^{34}$ remains difficult to reconcile with his support for the judicial tasks as an AB judge. The conclusion

31 Graham, supra note 28, at 11.

32 On these three dimensions of legal interpretation, see G.Abi-Saab, Introduction: A Meta-Question, in EvoluTiONARY INTERPRETATION AND INTERNATIONAL LAW 7-12 (G.Abi-Saab et al. eds., 2019).

33 Appellate Body Report, Chile-Alcoholic Beverages AB Report, WT/DS110/AB/R, Chile-Alcoholic Beverage, 979 , WTO Doc. WT/DS110/AB/R (adopted Jan. 12, 2000). For an explanation of the interpretative approaches of the AB, see P. van den Bossche \& W. Zdouc, the Law and Policy of the World Trade Organization. Text, Cases and MAterials 190ff (4th ed. 2017).

34 Graham, supra note 28. See also It Sure Looks Different from the Inside, and Now the Outside Too? (or "Graham on Graham”), International Economic Law and Policy Blog (Mar. 11, 2020), available at https://ielp.worldtradelaw. net/2020/03/it-sure-looks-different-from-the-inside-and-now-the-outside-too-or-graham-on-graham.html?utm source $=$ feedburner\&utm_medium $=$ feed\&utm_campaign $=$ Feed $\% 3 \mathrm{~A}+\mathrm{ielpblog}+\% 28$ International + Economic + Law + and + Policy+Blog $\% 29$. 
of Graham's 2020 speech-“[t]he Appellate Body is gone and it is not returning,"35flatters the USTR; but it fails to convince the 120 WTO members requesting, at each DSB meeting, to proceed to the filling of $\mathrm{AB}$ vacancies. The contradictory reasoning of Graham offers a taste of how contradictory WTO dispute settlement practices risk becoming without appellate review of panel reports pursuant to Article 17 of DSU. Graham suggests in his 2020 speech that the AB should limit itself to reviewing "whether the panel made a serious error" without creating "a body of jurisprudence or to head off future disputes." Such a limitation of AB review would not only be inconsistent with the text of the DSU as interpreted by the AB and all WTO members during 25 years. It would also undermine the central DSU objective of "providing security and predictability to the multilateral trading system' in the "prompt settlement" of WTO disputes through quasi-judicial clarifications of "the existing provisions of those agreements in accordance with customary rules of interpretation of public international law" (Article 3.2 of DSU).

Fortunately, among the 27 AB members since 1995, Graham remains the only one who seems to be proud of now pleading for the destruction of what he himself praised in 2013 "as the most successful international dispute settlement system in the history of the world." History confirms that legal civilization evolves dialectically; unfortunately, it remains never guaranteed-unless citizens defend PG and "public reason" and resist intergovernmental power politics. The DSU and its AB system can certainly be improved, even though these DSU reform negotiations in special DSB sessions since 1998 have so far eluded any agreements. But neither the 164 WTO members nor their citizens have reasonable self-interests in destroying the uniquely successful AB system of the WTO. How should citizens, democratic institutions and the WTO institutions respond at a time when the USTR is waging ever more trade wars and withdraws from global PGs treaties like the 2015 Paris Agreement on climate change mitigation? Should the WTO members and civil society accept President Trump's opportunistic view that the WTO "sustainable development" objective can be achieved without the 2015 Paris Agreement? ? $^{36}$

35 Graham, supra note 13 , at 6.

36 On the need for "greening the embedded liberalism' underlying WTO law," see Petersmann, supra note 18. 


\section{V.WTO ADJUDICATION@me.too: Citizens must Defend Public Reason}

Global PGs (res publica)-like the WTO legal and dispute settlement as an indispensable building block for realizing the UN 2030 sustainable development goals and climate change mitigation - cannot be effectively protected without support from civil societies and democratic institutions (e.g. limiting fossil fuel consumption, fishery subsidies, "green house gas emissions" and environmental pollution by plastics). The "law in the books" depends on social support and respect by citizens in order to remain an effective "law in action" (e.g. limiting environmental pollution by millions of citizens). In order to protect global PGs, civil societies must hold accountable governments and democratic institutions as a "global virtual republic," for instance by challenging illegal power politics through the social media and supporting the WTO institutions in protecting transnational rule-of-law. In his book on THE WILLING World: SHAPING AND SHARING A SUSTAINABLE GLOBAL PROSPERITY, former US congressman and WTO AB judge J.Bacchus begins by asking his readers: Will you join with others working now to find the "right way to make life better for billions of people on our imperilled planet"? ${ }^{37}$ Unless citizens join "this willing world" and actively support global PGs, the existential citizen interests in transnational rule-of-law protecting "sustainable development" will not be effectively protected. As the AB remains part of the "WTO law in the books," all 164 WTO members remain legally required to honor their obligations to protect the $\mathrm{AB}$ as defined in Article 17 of DSU (e.g. by filling $\mathrm{AB}$ vacancies by majority decisions as prescribed in Article IX:1 of the WTO Agreement, with a pragmatic "opt out" for the WTO members illegally abusing their veto-powers). ${ }^{38}$ As long as no parliament has approved the illegal and undemocratic de facto amendment of the DSU imposed by the USTR, the "virtual cosmopolitan republic" of responsible citizens should remind their WTO representatives of the fact (albeit hidden in plain sight) that the WTO law and the DSU prescribe protecting rule of law through national and international judicial remedies, even if the DSU avoided, at the request of the US negotiators, describing the WTO panelists, AB members and arbitrators as 'judges.' Of course, the WTO system of third-part adjudication remains

37 J. Bacchus, The Willing World: Shaping and Sharing a Sustainable Global Prosperity ix (2018).

38 On the interpretation of Article IX.1 of the WTO Agreement (i.e. enabling to overcome illegal abuse of veto-powers in the DSB), see E.-U.Petersmann, Between "Member-Driven Governance” and 'Judialization': Constitutional and Judicial Dilemmas in the World Trading System, in The ApPellate Body of the WTO AND ITs Reform 15-42 (Chang-fa Lo et al. eds., 2020). 
uniquely sui generis. ${ }^{39}$ Yet, prior to the conversion (with his speech of March 5, 2020) of T. Graham from a WTO judge to an USTR supporter, the USTR remained isolated in denying (quasi)judicial functions of the WTO third-party adjudication. Similarly, the USTR has failed in its efforts at destroying the social and legal legitimacy of AB jurisprudence, even if the previously celebrated "crown jewel" of the WTO dispute settlement system has been stolen by the USTR without any intention of giving it back. ${ }^{40}$ Compared with other WTO members, the USTR seems to have been the most successful litigator in the past WTO dispute settlement practices. Yet, it remains isolated in its efforts at de-legitimizing the $A B$; most $A B$ findings continue being supported and implemented by the WTO membership. Without the illegal USTR blocking of the filling of $A B$ vacancies, the DSB and the $A B$ would have continued to discuss and adopt AB reports. In its "special sessions," the DSB is likely to continue seeking agreement on reforms of the WTO dispute settlement system, including the AB. Can the legal and democratic legitimacy dilemmas of the WTO's "AB crisis" and the "political failures" of WTO governments to adjust WTO law to the regulatory challenges of the 21st century, be reduced by enhancing "social legitimacy" and "public reason" through more inclusive WTO deliberations?

\section{A. Citizens as "Democratic Principals" of Multilevel Governance Agents?}

Responsible citizens - as the "democratic principals" of government agents and as a cosmopolitan 'republic@me.too' interested in defending rule-of-law against power politics - should promote not only human rights, gender equality and climate change mitigation, but also protect other global PGs in order to prevent autocratic rulers from destroying "global PGs treaties" to the detriment of citizens all over the world.

39 For instance, the discussion, criticism, adoption and supervision of all of the more than 400 WTO panel and appellate reports by the DSB - acting on behalf of all WTO members-remains unique in international law and dispute settlement systems. Likewise, the institutionalized discussion of dozens of the WTO arbitration awards in the DSB, and the worldwide discussion of the WTO jurisprudence, promote a uniquely "responsive judicial system," whose constant interactions between law-makers, judges, government officials, academics and civil society discussing and criticizing the WTO dispute settlement findings promote adjustments of the "law in the books" and of the "law in action" to political and social criticism and regulatory needs, thereby promoting a more inclusive "living the WTO legal system" open for public criticism and the need for justifying law and jusrisprudence vis-à-vis citizens and economic actors affected by the WTO law. Unfortunately, the DSB has failed to hold the AB jurisprudence more politically accountable, for instance through a procedure for correcting judicial interpretations by majoritarian "authoritative interpretations" pursuant to Article IX.2 of the WTO Agreement.

40 E.-U. Petersmann, The Crown Jewel of the WTO has been stolen by US Trade Diplomats - and they have no Intention of Giving it back, in Restoring Trust in Trade - Liber Amicorum for Peter Van den Bossche 105-18 (D. Prevost et al., eds., 2018). 
Responsible citizens should start a WTO Adjudication@me.too "enlightenment campaign"- regardless of one's views about the obvious need for reforming the WTO dispute settlement system and the ruthless neo-liberalism and illegal power politics dominating the WTO negotiations. As the DSB and the USTR have grossly failed in this task of "institutionalizing public reason" in WTO adjudication, today's "social media generation" - which, according to the 2019 UN "Sustainable Development Goals" Report, ${ }^{41}$ risks being confronted with 140 million climate change refugees by 2050 should follow the courageous example of Swedish climate activist Greta Thunberg by challenging their local teachers and democratic representatives. ${ }^{42}$ For example, why do most worldwide organizations and related textbooks on the politics ("memberdriven WTO governance"), economics and law of governing international PGs - with few exceptions (like human rights and ILO bodies, the 17 UN sustainable development goals, EU law, my own book, INTERNATIONAL ECONOMIC LAW IN THE 21sT CENTURY)-avoid justifying international rules and institutions by "principles of justice," which citizens can understand and support? Why do democratic parliaments (like the US Congress) so often fail to 'embed' the WTO rules more effectively into domestic governance systems so that citizens can invoke and enforce international rules in domestic jurisdictions? Why do Washington trade remedy lawyers, who pity themselves as 'losers' of AB jurisprudence, have such disproportionate influence in the US politics and the WTO governance? Why do "realist US lawyers" ridicule proposals that citizens must assume "cosmopolitan responsibility" for protecting PGs in a globalizing world without strong democratic leadership and with an increasing number of autocratic rulers, who disdain judicial accountability and cosmopolitan conceptions of the international law community as including citizens? As the current "global crises" of the world trading, health, environmental and rule-of-law systems threaten the lives of millions of people: Is it reasonable for civil societies to wait for still another "wake-up call" in order to hold intergovernmental power politics more accountable?

\section{B. Are Citizen-driven WTO Deliberations Politially Unrealistic?}

In October 2020, the WTO's annual "Public Forum" with hundreds of nongovernmental organizations ("NGOs") initiating public deliberations with the WTO diplomats is scheduled to discuss "Building on 25 years of the WTO." Like the

41 UN, The Sustainable Development Goals Report (2019), at 3, 42 \& 48, available at https://reliefweb.int/sites/reliefweb. $\mathrm{int/files/resources/The-Sustainable-Development-Goals-Report-2019.pdf.}$

42 On Greta Thunberg (a 17 year old Swedish schoolgirl) and her actions (e.g. in Sweden, the EU and the UN institutions) in support of climate change mitigation, see Greta Thunberg TwITTER, available at https:/twitter.com/ GretaThunberg?ref_src=twsrc\%5Egoogle\%7Ctwcamp\%5Eserp\%7Ctwgr\%5Eauthor. 
regular meetings of members of parliaments inside the WTO, the annual public fora offer important opportunities for civil society and members of parliaments to discuss political and legal world trade problems with the WTO diplomats and officials. Inside constitutional democracies, rule-of-law tends to prevail because citizens and NGOs can invoke constitutional and legislative rules, administrative decisions, governmental declarations and, if necessary, enforce rule-of-law through courts of justice. Similarly, European common market law and human rights law remain effective because more than 500 million citizens and (non)governmental economic actors can invoke and, if necessary, enforce regional economic and human rights regulations in national and European governance institution and courts of justice like the European Court of Justice ("CJEU"), the European Free Trade Area ("EFTA") Court, or the European Court of Human Rights ("ECtHR"). Even though many governments deny rights of their citzens to invoke the WTO legal rights and obligations in domestic jurisdictions: Would it not be in the interest of citizens and democratic institutions to strengthen the WTO's "embedded liberalism"43 by holding the WTO diplomats more accountable for their intergovernmental WTO power politics? Just as all WTO panel and appellate reports tend to be discussed and criticized in most WTO member states by academics and professionals, the WTO governance could enormously benefit from broader engagement with civil societies and democratic institutions defending "public reason."

Inside the WTO institutions, diplomats must respond constructively to the power politics of the Trump administration. The criticism of the USTR confirms the obvious need for reforming the WTO dispute settlement system. In their DSU reform negotiations since 1998, the DSB and the USTR have grossly failed in their task of "institutionalizing public reason" in the WTO adjudication. As the illegal US destruction of the WTO AB system undermines predictability and enforceability of the WTO rules, the future of WTO negotiations on adjusting other WTO rules to the regulatory requirements of the 21st century risks being undermined. This "systemic WTO crisis" risks impeding multilateral negotiations and regulatory reforms also

43 This term was coined for describing the dual GATT 1947 objectives such as international trade liberalization and domestic political autonomy (e.g., to regulate markets and their social adjustment problems, and to stabilize the economy in case of external shocks). For detals, see J. Ruggie, International regimes, transactions and change: Embedded liberalism in the postwar economic order, 36 INT'L ORG. 379-415 (1982). My use of the term differs from that by A. Lang, who describes the period from 1947 to the early 1970s as "the period of embedded liberalism" and the following period up to around 2000 as "the neoliberal turn." See A. LANG, World Trade LaW after Neoliberalism 16-7 (2011). While some Tokyo Round and Uruguay Round Agreements and national trade policies in some GATT/ WTO member states pursued neo-liberalism since the late 1970s, other GATT/WTO agreements (like the 1979 GATT "Enabling Clause," the DSU) and domestic economic law developments (e.g. in EU competition, monetary, social and environmental regulation) did ordo-liberal regulation rather than deregulation and liberalization of markets. 
outside the WTO, notably multilateral cooperation in responding to global crises like climate change mitigation, health pandemics, and the related risks of global economic and financial crises. ${ }^{44}$ There are many possible ways of reforming the "AB 2019." Hence, the WTO members should continue responding to the US concerns and to the "convergence principles" proposed by Ambassador Walker in his attempts at facilitating a solution to the $\mathrm{AB}$ crisis by finding a "new $\mathrm{AB}$ compromise" acceptable to all WTO members including the US. The above proposal for a citizen-driven "WTO Adjudication@me.too enlightenment campaign" could assist these WTO negotiations by pursuing three modest objectives: Reasonable and responsible citizens, businesses, other civil society and democratic institutions inside the 164 WTO members should:

(1) reject the USTR denial of any (quasi)judicial function of the WTO dispute settlement system, which is plainly inconsistent with the WTO and DSU legal texts $^{45}$

(2) acknowledge that multilateral third-party adjudication (including WTO adjudication) is a global PG of existential importance for the pursuit (e.g. in the context of the 2015 Paris Agreement and of the WHO) of economic and social welfare of billions of citizens all over the world; and

(3) further acknowledge that the "cosmopolitan responsibility" for protecting global PGs requires respecting the democratic decisions of the 164 WTO members and their democratic institutions to comply with the - obviously imperfect - WTO rules until WTO members agree on lawful ways of improving or correcting them.

Such a political endorsement of rule of law and constructive WTO negotiations must leave the details of the DSU reforms to the WTO diplomats and negotiators. Yet, the list of legal methodology questions drawn up by Graham for his former $\mathrm{AB}$ colleagues remains a distraction: in any judicial system, interpretative methods - within the constraints prescribed by the applicable law - remain a matter for each individual Justice to decide, as long as each Justice adopts a legally consistent method in good faith and remains open to modifying his/her interpretive method in response to the

Unfortunatly, similar to his decision to withdraw the US from the 2015 Paris Agreement on Climate Change Mitigation, in April 2020, President Trump threatened the World Health Organization to suspend the US financial contributions.

45 Graham's invocation of "the negotiating history" for justifying USTR interpretations (e.g. that the Appellate Body was "intended $[\ldots]$ as a check on occasional egregious mistakes by panels") is plainly inconsistent with the agreed legal texts, with their interpretations by the WTO litigants and the WTO appellate reports as adopted by the DSB over 25 years, as well as with the fact that there does not exist any officially agreed "negotiating history" of the Uruguay Round negotiations. Having served myself as secretary of the Uruguay Round Negotiating Group 13 that elaborated the DSU, I recall that the 'minutes' recording some of the negotiations remained incomplete, and many of the restrictive US proposals were opposed by other delegations and not incorporated into the finally agreed treaty texts. 
judicial arguments of his/her colleagues. ${ }^{46}$ Judicial responses to external criticism of the AB (e.g. from the USTR) may be legally justifiable, even if judges inspired by R.Dworkin's “Justice Hercules” may resist political pressures. But Graham's advice to give up the AB's collegiality tradition is toxic for an appeal body deciding by consensus or majority in Divisons composed of three AB members: as the interpretive methods of judges may legitimately differ (as reflected in some of Graham's dissenting opinions in $\mathrm{AB}$ reports), collegial deliberations among all $\mathrm{AB}$ membersand collective justifications of their reasoning-are the essence of the social and legal legitimacy of their (majority) judgments.

In the DSB, government representatives legitimately challenge some legal AB interpretations (e.g. of "public bodies" in WTO subsidy disciplines) on political grounds. However, most WTO diplomats wisely avoid political interferences with judicial methodology issues (e.g. judicial duties of justifying "right interpretations"), for example, in view of the WTO's separation of legislative, executive and judicial governance functions (cf. Article III of the WTO Agreement) and the opportunist USTR denial of any (quasi)judicial functions of the WTO dispute settlement system. The WTO diplomats should use political DSB decisions for criticizing or correcting $\mathrm{AB}$ legal findings, for instance, by authoritative interpretations adopted by a threefourths majority of the WTO members as provided for in Article IX.2 of the WTO Agreement. Reasonable people have no reason to deny the WTO's third-party adjudication only because the Trump administration wishes to impose its power on the rest of the world without judicial constraints. Civil societies should support and remind their governments that they have no democratic legitimacy to ignore worldwide PGs treaties (e.g. Article 17 of DSU). Parliaments have given no such mandate to their government executives - an illegal destruction of the $\mathrm{AB}$ risks undermining the whole WTO legal and dispute settlement system as prescribed in the WTO Agreement and approved by parliaments. North-American advocates for a unilateral burial of the $\mathrm{AB}$ ("Let the $\mathrm{AB}$ rest" on the cemetery of power politics) forget too easily that the $\mathrm{AB}$ remains part of a worldwide treaty approved by parliaments in 164 WTO members on behalf of their citizens! Is it 'unrealistic' to request citizens to overcome the "feudal disconnect" ("trust your diplomats") between "member-driven WTO governance" and citizens, whose human and democratic rights are nowhere mentioned in the WTO law? 


\section{Conclusion: Time for Reconceptualizing International Law as Multilevel Governance of Public Goods for the Benefit of Citizens}

If human society is perceived as a system of human self-ordering under law, globalization requires citizens to recognize themselves as cosmopolitan "citizens of the world" rather than only as national citizens of this or that state: Our primary identity is our shared humanity. ${ }^{47}$ As the UN human rights law and constitutional democracies protect democratic participation in the exercise of government powers, citizens must resist "destructive abuses" - and promote reasonable "constructive uses" - of multilevel governance powers. European integration law illustrates how such citizen-driven "legal civilization" - also of intergovernmental power politics can effectively re-constitute international society. ${ }^{48}$ Civil societies must struggle for 'constitutionalizing' international law and international organizations so as to protect multilevel governance of PGs against abuses of public and private power. In Europe, national and European courts recognize European integration law among the $27 \mathrm{EU}$ member states - as well as the European Convention of Human Rights ("ECHR") - as multilevel constitutional law systems protecting "EU citizens" and their constitutional and human rights (e.g. as codified in the EU Charter of Fundamental Rights and in the ECHR). Outside Europe, many national and international lawyers and diplomats continue neglecting "constitutional challenges" such as:

- Why were so many historical 'half-revolutions' - like 1688 in Britain, 1781 in America, 1789 in France, 1917 in China and Russia, and 1919 in Germany followed by constitutional failures in reforming national legal systems?

- Why have international treaty 'constitutions' (sic) establishing the ILO, the WHO, the Food and Agriculture Organization (FAO) and the UN Educational, Scientific and Cultural Organization (UNESCO) so often failed to realize their constitutional mandates in international relations?

47 This cosmopolitan re-interpretation of international law follows from the universal recognition of inalienable human rights and their jus cogens core. Yet, it is also shared by critics of the UN human rights law. For details, see P. AlLotT, Eunomia: New Order for a New World (1990); Eutopia. New Philosophy and New Law for a Troubled World (2016). For details on my critique of Allott's "evolutionary constitutionalism" and my arguments for "constructivist constitutionalism," see E.-U. Petersmann, "Constitutional Constructivism" for a Common Law of Humanity? Multilevel Constitutionalism as a "Gentle Civilizer of Nations." in Max Planck Institute of International Law Research Paper SERIES No. 2017-24, available at https://papers.ssrn.com/sol3/papers.cfm?abstract_id=3054442.

48 E.-U. Petersmann, Lessons from European Constitutionalism for Reforming Multilevel Governance of Transnational Public Goods in Asia?, in Sixty Years of European Integration and Global Power Shifts: Perceptions, Interactions AND Lessons 217-37 (J. Chaisse ed., 2020). 
- Why is the customary law requirement of interpreting treaties not only on the basis of the text, context, object and purpose of treaty provisions (cf. Article 31:1 Vienna Convention on the Law of Treaties), but also 'in conformity with the principles of justice', including also "human rights and fundamental freedoms for all" (as codified in Article 31:3 and the Preamble of the VCLT), so often disregarded in national and international legal and judicial practices?

- What are the lessons for multilevel governance of PGs beyond Europe from the successful 'constitutionalization' of European integration law resulting from the empowerment of citizens as legal subjects and "democratic principals" of multilevel governance through EU law, the European Economic Area (EEA) and the ECHR?

- Can multilevel "judicial constitutionalization"-for example, in response to requests for "preliminary rulings" from the CJEU, 'advisory opinions' from the EFTA Court, and judgments by the ECtHR-be extended beyond Europe? Are judicial control of abuses of executive powers - and judicial enforcement of international treaties approved by democratic parliaments - justified by popular sovereignty, limited delegation of powers for "government of the people, by the people and for the people," and judicial protection of "constitutional rights retained by the people?",4

The responses to these and other "constitutional challenges" will inevitably differ among countries according to their constitutional traditions and democratic preferences. This concluding section briefly explains why globalization and its transformation of national into transnational PGs require multilevel constitutional protection of multilevel governance of PGs, as it has evolved in diverse forms in regional and UN/WTO law and governance through multilevel judicial interpretation and protection of rule-of-law and individual rights in international trade and commercial law, investment law, human rights law and international criminal law. The WTO governance crises-like the current global health and environmental crises-illustrate why the lack of democratic accountability of intergovernmental power politics visà-vis adversely affected citizens and their democratic institutions undermines the legitimacy, legal restraints and democratic effectiveness of multilevel governance of PGs. It must be overcome through participatory democracy (e.g. challenging President Trump's nationalist denial of climate change) and empowerment of citizens. Struggles for republican and cosmopolitan 're-constitution' of multilevel governance of transnational PGs must promote citizen-oriented re-interpretations of international law, their support by democratic institutions and judicial protection by courts of justice. Just as the UN human rights law has enabled a successful

49 Petersmann, supra notes $8 \& 48$. 
decolonization of international relations, citizens must continue their struggles for progressively 'constitutionalizing' abuses of intergovernmental power politics like the US destruction of the WTO AB.

\section{A. Why Do Citizens Need Ordo-liberal "Economic Constitutionalism"?}

Human survival and flourishing depend, inter alia, on consumption of private goods (like food, clothes, housing, medicines) and PGs (like legal order, public education, peace). Since the invention of modern economics by Adam Smith in the 18th century, economists emphasize that private goods tend to be produced spontaneously and efficiently in competitive markets provided:

- private property rights and voluntary market exchanges are protected (e.g. by contract law, property law, judicial remedies);

- "market failures" as well as "governance failures" are legally restrained; and

- social injustices are limited (e.g. by socializing and embedding the division of labor in "social market economies" as prescribed by EU law).

PGs - due to their non-rival and non-excludable consumption and lack of incentives for commercial supply in private markets-require collective supply by governments or private-public partnerships. Anglo-Saxon neo-liberalism (e.g. as advocated by "Chicago School" economists) focuses on liberalization of market access barriers, economic deregulation and privatization of economic activities, and 'financialization' of markets in order to reduce the scarcity of goods, services and other resources by setting incentives for "utility maximization" by the homo economicus driven by the self-regulatory forces of market competition (as spontaneous information-, coordination-and sanctioning-mechanism). ${ }^{50}$

European ordo-liberalism criticizes neo-liberal economists and politicians for their frequent neglect of "market failures" (like abuses of power, adverse external effects, information asymmetries, social injustices due to inadequate supply of PGs), governance failures (like welfare-reducing protectionism) and "constitutional failures" (like inadequate protection of economic freedoms, property rights, labor rights, other fundamental rights of citizens, rule of law and judicial remedies). ${ }^{51}$ Ordo-

\footnotetext{
50 For detailed comparisons of utilitarian, neo-liberal Chicago-school economics and rights-based, European "ordoliberalism" and "Virginia-school constitutional economics," see Petersmann, supra note 18 and Slobodian, supra note 17, at 7ff. On the underlying "law and economics," see E.-U. Petersmann, Constitutional Functions and Constitutional Problems of International Economic Law. International and Domestic Foreign Trade Law and Policy in the United States, the European Community and Switzerland 49-95 (1991, 2020 reprint).

51 For details, see Petersmann, supra note 18.
} 
liberalism emphasizes the need for:

- legally constituting non-discriminatory market competition (rather than perceiving markets as gifts of nature);

- legally limiting market failures as well as governance failures; and for

- defining economic values more comprehensively in conformity with the democratic preferences of people (e.g. in terms of human capacities and basic human needs as protected by human and constitutional rights of citizens). ${ }^{52}$

The paradigm of "utility maximization" (e.g. in terms of Pareto-and Kaldor-Hicksefficiencies) must be supplemented by "exchange-and social contract paradigms" defining "efficient rules" by mutually beneficial agreements among citizens protecting their individual and democratic preferences (e.g. for protecting human needs and capabilities by equal human and constitutional rights limiting abuses of governance powers). For example, the EU's "micro-economic common market constitution,"53 "macro-economic monetary constitution," review ${ }^{55}$ were strongly influenced by German and European ordo-liberalism. ${ }^{56}$ Due to its "principled thinking" - for example in terms of "interdependent, rules-based orders"; "governing through market mechanisms," and republicanism protecting PGs (res publica),- ordo-liberalism emphasizes that the competitive order (safeguarding the proper functioning of performance competition and price mechanisms) must remain embedded into mutually coherent monetary order (e.g. protecting price stability, fiscal discipline), democratic constitutionalism (e.g. holding "European network governance" accountable through multilevel competition, monetary and other regulatory agencies) and social order (protecting labour markets, welfare states and social justice). The Charter of Fundamental Rights of the European Union ("EUCFR") guarantees of civil, political, economic, social and "European citizenship rights" protect not just "negative freedoms" (e.g. constraining abuses of public and private power). Rather,

$52 \quad I d$.

53 It is based on multilevel common market freedoms, competition, environmental and social rules, multilevel competition institution, and "regulatory competition" constrained by multilevel judicial protection of civil, political, economic and social rights.

54 It is based on EU legal disciplines for monetary, fiscal, debt and economic policies supervised by multilevel, independent central banks and intergovernmental economic cooperation.

55 H. Hofman, K. Pantazatou \& G. Zacacaroni (eds.), The Transformation of the European Economic Constitution (2019). See also C. Kaupa, The Pluralist Character of the European Economic Constitution (2016).

56 On the EU's sectoral (e.g. micro-economic, macro-economic and social) 'constitutions,' see K. TuORI, EUROPEAN Constitutionalism $127 \mathrm{ff}$ (2015). On "constitutional economics" and the controversies over applying ordo-liberalism to the EU's monetary union, see generally T. Biebricher \& F. Vogelmann (eds.), The Birth of Austerity: German Ordoliberalism and Contemporary Neoliberalism (2017). 
rights to facilitate "positive freedoms" through governmental protection of individual self-development (e.g. "human dignity") can be seen as constitutional core values of the "social market economy," for instance, protecting labour, health, environmental rights and public education. The "social market economy" progressively established in Germany since the 1960s, and the EU law commitments to a "competitive social market economy" ${ }^{, 57}$ with ever more guarantees of social rights structured around three priorities-equal opportunities for education, professional training and access to labor markets; fair working conditions; and access to social protection and health care for all-illustrate how ordo-liberal constructivism differs from neo-liberal faith in self-regulatory capacities of markets. Also, Asian countries continue to define their national conceptions of "embedded liberalism" in legitimately diverse ways differing from utilitarian, Anglo-Saxon neo-liberalism and from ordo-liberal, European constitutionalism, for instance, by cultivating more communitarian and Confucian "Asian value" traditions.

\section{B. Globalization Requires Transnational Constitutionalism}

Almost all UN member states have adopted national Constitutions (written or unwritten) for the collective supply of national PGs in conformity with democratic preferences of peoples. Comparative constitutional law confirms the reality of "constitutional pluralism": each national Constitution responds to the particular histories, contexts and preferences of peoples and differs from other national Constitutions. The more globalization transforms national into transnational PGs which no state can protect unilaterally without international law and international organizations (like protection of health against global health pandemics, climate change mitigation, a mutually beneficial division of labor, rule of law), the more national Constitutions ('constitutionalism 1.0' protecting national PGs) - and functionally limited, international 'treaty constitutions' ('constitutionalism 2.0' like the ILO, FAO, WHO, UNESCO 'constitutions')-must be coordinated and integrated through multilevel constitutional safeguards, like multilevel judicial protection of transnational rule-of-law and human and constitutional rights of citizens ("constitutionalism 3.0" underlying diverse regional human rights treaties, economic integration and environmental protection agreements with multilevel governance institutions).

In Africa, Europe and Latin-America, states increasingly responded to abuses of power by concluding regional human rights conventions and economic integration agreements with multilevel legislative, executive and judicial governance powers.

57 Treaty of Lisbon amending the Treaty on European Union and the Treaty establishing the European Community, art. 3. 
Also in other world regions (like Asia and North-America), the frequent disregard for "global PGs agreements" (like the UN human rights conventions, the UN Convention on the Law of the Sea, the WTO and 2015 Paris Agreements) requires multilevel constitutional restraints on abuses of governance powers in order to protect rights and welfare of domestic citizens more effectively.

For instance, international trade and investment law progressively evolved from (1) international private and commercial law (as legal basis for most international economic transactions) and (2) international agreements among states (like the 1944 Bretton Woods Agreements, GATT, other trade and investment treaties) into (3) multilevel economic regulation (e.g. as reflected in GATT/WTO law), (4) "global administrative law" and (5) functionally limited "economic constitutionalism" (like EU and EEA common market law as interpreted and protected by national and European courts). ${ }^{58}$ International investment law dynamically evolves through more than 3,200 bilateral and regional investment treaties, more than 1000 known investorstate arbitral awards, and protection of investor rights through national and regional economic and human rights courts aimed at reconciling investor rights with all other governance interests and human and constitutional rights of citizens. ${ }^{59}$ National and international human rights law and environmental law are progressively integrated through rule-making, administration and judicial remedies in the UN, regional and national human rights bodies. European economic integration and human rights law have protected 'democratic peace' among the 27 EU and 47 ECHR member states more effectively than any peace treaties before World War II. This European experience confirms that multilevel constitutionalism, even if functionally limited to certain policy areas like regional common markets and international trade law, can be of existential importance for protecting PGs across national borders.

\section{Is Democratic and Cosmopolitan Constitutionalism as Restraints on the WTO Power Politics?}

During most of the recorded history of the homo sapiens, law and governance of PGs were justified by "mandates of heaven" and "divine rights" invoked by feudal rulers. When the "first humanism" since about 500 BC enabled the emergence of autonomous rather than heteronomous political and legal orders, democratic constitutionalism (e.g. in ancient Athens) and republican constitutionalism (notably in ancient Rome) were

58 Petersmann, supra note 7, ch. I.

59 For empirical and legal analyses, see E.-U.Petersmann, Can Invocation of Human Rights Enhance Justice and Social Legitimacy in Investment Adjudication?, 12 INDIAN J. INT'L ECON. L. (2020, forthcoming). 
designed and justified (e.g. by political philosophers like Plato, Aristotle and Cicero) as more legitimate and more effective, political strategies for protecting PGs for the benefit of citizens. They empowered the ancient Athenian and Roman city republics to protect internal and external peace and trade in large parts of the Mediterranean. Democratic constitutionalism focused on improving the input legitimacy of law and governance through citizenship rights, democratic elections, participatory democracy (e.g. in popular assemblies and armies), deliberative democracy and institutional "checks and balances" (e.g. among legislative, executive and judicial institutions).

Republican constitutionalism focused on additional constitutional mandates and restraints aimed at improving the output legitimacy of law and governance (e.g. in terms of protecting non-domination, judicial remedies of Roman citizens and other PGs like the Roman legal system that became accepted by many other jurisdictions throughout Europe).$^{60}$ Even after the ancient city republics around the Mediterranean ceased to exist due to the West and East Roman empires, new city republics emerged in Florence, Venice and the Northern European city republics participating in the "Hanseatic League" protecting peace and trade throughout the Baltic sea. They developed new law and governance institutions such as maritime law, transnational financial law, arbitration protecting multinational banks and investments that continue to influence modern legal systems. The "human rights revolutions" of the 18th century paved the way for new kinds of 'cosmopolitan constitutionalism'. As all UN member states have ratified one or more UN human rights conventions protecting 'inalienable' human rights, this contribution began by suggesting that, in the 21st century, international "PGs treaties" should be re-interpreted as protecting rights and obligations not only of states and governments, but also of peoples and citizens as subjects of inalienable human and democratic rights to hold governments accountable for their exercise of limited, delegated governance powers. The WTO Agreement derives democratic legitimacy not only from the consent of states, but also of parliaments and democratic institutions on behalf of their citizens. Also, the reunification of politically divided states-for example, in China, Germany and Korea -derives its political legitimacy more from respect for human rights and democratic self-determination than from political fiat.

The welfare-enhancing WTO treaty objectives (like promotion of "sustainable

60 There is disagreement on whether "freedom as non-domination," civic virtues, active citizenry, political equality, selfgovernment, rule of law, the community, the common good or the struggle against domination are the core values of 'republicanism.' Modern liberal and republican theories overlap (e.g. regarding separation of powers and of public and private spheres). In national and international law, republicanism is more ancient than liberalism and majoritarian democratic decision-making. 
development") and their effective pursuit also depend on citizens engaging in mutually beneficial trade and investments and protecting the global PG of rulesbased, political and judicial governance preventing and settling international trade disputes peacefully. Hence, Parts III to V of this contribution called on reasonable citizens and their democratic institutions to actively support WTO governance through a "WTO Adjudication@me.too enlightenment campaign" so as to protect independent and impartial WTO adjudication and transnational rule-of-law against the arbitrary assault by the USTR on the AB of the WTO. As citizens all over the world have discussed, criticized or supported the more than 400 WTO dispute settlement reports over the past 25 years, they should let their governments know that an illegal destruction of the $\mathrm{AB}$ risks adversely affecting not only traders, but also the welfare of many other citizens.

Law (e.g. as self-commitment to rules of a higher rank) is part of individual and social self-constitution in order to realize "personality' (e.g. one's "moral powers" and legal rights to pursue a "good life" and "social justice") and order society. Constitutionalism differs from feudalism and dictatorship, inter alia, by the ideas that: (1) all legal public power must be justified by and vis-à-vis citizens and exercised for the benefit of all citizens; (2) delegation of powers must remain limited and accountable subject to agreed "higher law" as acts of individual and social selfconstitution; (3) constitutional "checks and balances" among legislative, executive, judicial and other regulatory agencies must limit abuses of power at national and international levels of governance. ${ }^{61}$ It has developed as a "social contract" theory on the relationship between the source of the authority of political power (potestas government of the people), the control of its limited delegation and exercise (auctoritas - government by the people), and of the duty of governments to protect PGs for the benefit of citizens (res publica-government for the people), with due respect for the reality of "constitutional pluralism." Constitutionalism evolved differently in different societies, for instance depending on the ideas prevailing in particular societies regarding the relationships of their own legal, ideal and real social orders (e.g. justification of legal rules and ultimate sources of public authority by religious beliefs, or by "social contracts" constructing social and legal order). Human ideas and social practices of constitutionalism distinguish between the legal constitution (e.g. as reflected in the positive law of a society), the underlying constitutional ideals (e.g. the constitutional mandates for realizing a better future), and the real constitution (e.g. abuses of power and other "constitutional failures" in social realities). This 
contribution emphasized that, today,

- almost all 193 UN member states have adopted national (big C) Constitutions (written or unwritten) constituting, limiting, regulating and justifying the basic legal order of their respective peoples based on agreed "principles of justice," which are progressively clarified and developed through national and international legal instruments (like treaty commitments to respect human rights, rule of law, democratic self-governance and protection of other, transnational PGs for the benefit of citizens);

- this positive, yet inevitably incomplete constitutional law also includes mandates for the progressive realization (e.g. through additional constitutional, legislative, administrative, judicial and international rules and institutions) of an imagined ideal constitution (e.g. as reflected in UN human rights law and in the universally agreed 2015 "sustainable development goals" of UN member states);

- the social and constitutional realities often differ from the constitutional law and ideals set out in the multilevel constitutional commitments adopted by peoples and governments in the name of their citizens. For instance, inside many UN member states and in some UN institutions, some governments do not effectively protect human and constitutional rights of citizens and corresponding PGs as prescribed in national Constitutions, in UN law or regional human rights law.

This dialectic between imperfect constitutional law, constitutional ideals and constitutional realities is part of the "human condition" and of the complex, yet imperfect realities of "cosmopolitan constitutionalism." According to K. Mahbubani, Singapore's long-time ambassador to the UN, the "biggest gift the West gave the Rest was the power of reasoning," which "seeped into Asian minds gradually, through the adoption of Western science and technology and the application of the scientific method to solving social problems." He said:

East Asian societies, especially Japan and the "Four Tigers" (South Korea, Taiwan, Hong Kong and Singapore) were the first to absorb these ideas and practices, such as free market economics and empirical scientific research' ... "This spread of Western reasoning ... triggered three silent revolutions that explain the extraordinary success of many non-Western societies in recent decades" ... "The first revolution is political. For millenia, Asian societies were deeply feudal. The people were accountable to their rulers, not rulers to their people. "Oriental despotism" was a fair description of the political environments in all corners of Asia" ... "The rebellion against all kinds of feudal mind-sets which gained momentum in the second half of the twentieth century was hugely liberating for all Asian societies" ... 'in a big shift from previous 'despotic' assumptions, most Asian leaders now 
recognized that they are accountable to their people" ... "The second revolution is psychological: the Rest are going from believing that they were helpless voyagers in a life determined by "fate" to believing that they can take control of their lives and rationally produce better outcomes" ... "In the last thirty years, we have carried more people over the threshold of university education than we have in the previous 3'000 years" ... "The third revolution is in the field of governance" ... Fifty years ago, few Asian governments believed that good rational governance could transform their societies. Now most do. ${ }^{62}$

The main proposition of this contribution is to invite Asian lawyers and societies to participate in the democratic defense of the global PG of the WTO legal and dispute settlement system by requesting their governments to maintain the rules-based WTO third-party adjudication and resisting the illegal intergovernmental power politics and hegemonic mercantilism unilaterally imposed by the Trump administration. To answer the question raised in the title of this contribution: As inside democracies, citizens and peoples must be recognized also in multilevel governance of transnational PGs as "democratic principals" who must hold governance agents with limited, delegated powers accountable for protecting PGs and rule of law. The very active contribution of Asian countries - like China, India, Japan and Korea - to the evolution of the WTO legal and AB systems since 1995 reflects their reasonable self-interests in defending transnational rule-of-law in international trade. As China is expected to become the largest, national economy in the 2030s and has no reason to accept hegemonic US power politics, ${ }^{63}$ all WTO member states and their citizens have reasonable self-interests in using constitutionalism - as the most important political invention made in the history of mankind - for further restraining nationalist abuses of foreign policy powers, for instance through reforming and strengthening the WTO legal and AB systems protecting mutually reinforcing trade and environmental regulations for the benefit of citizens and our common future. This conclusion concords with environmental policy proposals that the 'anthropocene,' i.e., our new global context of humans having become a geophysical force provoking climate change, massive biodiversity losses and other geological changes that risk running out of human control - necessitates global constitutional approaches limiting obvious "governance failures" so as to prevent the human destruction of our environmental

63 For a comparison of the respective strengths and weaknesses of the Chinese and US "development strategies," and of the inappropriateness of comparing their geopolitical rivalries with the post-1945 "cold war," see generally K. Mahbubani, Has China Won? The Chinese Challenge to American Primacy (2020). 
52 E.-U. Petersmann

system. ${ }^{64}$ President Trump's invocation of "America first" for justifying the US assaults on the WTO law and the Paris Agreement on climate change mitigation pose unprecedented, global threats, which responsible citizens - also in less - developed countries, which risk being most adversely affected by the WTO power politics and climate change ${ }^{65}$-must not leave unchallenged.

Received: February 1, 2020

Modified: March 30, 2020

Accepted: May 15, 2020

64 L. Kotzé, Global Environmental Constitutionalism in the Anthropocene (2016).

65 See the UN Report on "Climate Change and Poverty," U.N. Doc. A/HRC/41/39 (June 25, 2019), - 11, available at https://documents-dds-ny.un.org/doc/UNDOC/GEN/G19/218/66/PDF/G1921866.pdf?OpenElement. 